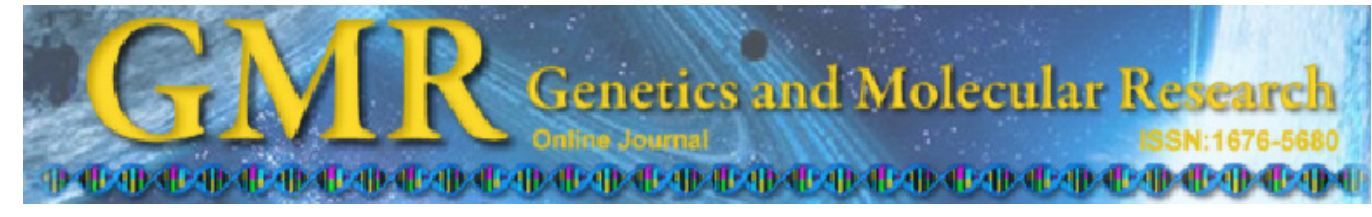

\title{
Molecular cytogenetics of nucleolar organizer regions in Phyllomedusa and Phasmahyla species (Hylidae, Phyllomedusinae): a cytotaxonomic contribution
}

\author{
A. Barth, V.A. Souza, M. Solé and M.A. Costa \\ Departamento de Ciências Biológicas, Universidade Estadual de Santa Cruz, \\ Ilhéus, BA, Brasil \\ Corresponding author: M.A. Costa \\ E-mail: costama@uesc.br
}

Genet. Mol. Res. 12 (3): 2400-2408 (2013)

Received January 10, 2013

Accepted June 14, 2013

Published July 15, 2013

DOI http://dx.doi.org/10.4238/2013.July.15.3

\begin{abstract}
Chromosome numbers, morphology, and nucleolus organizer region (NOR) locations are useful cytological characters for taxonomic and evolutionary studies. In this study, we provide the first cytogenetic analysis of Phyllomedusa bahiana and Phasmahyla spectabilis, and report new cytogenetic data on variation in NOR numbers and positions in Phyllomedusa rohdei and Phyllomedusa nordestina using conventional staining, AgNOR-banding, and 45S rDNA fluorescence in situ hybridization. All 4 species showed $2 \mathrm{n}$ $=26$ chromosomes. $P$. spectabilis and $P$. bahiana had only 1 pair of NOR-carrying chromosomes. $P$. bahiana showed an NOR length polymorphism, and a rare homomorphic self-compatibility for both NOR lengths in anurans. Variation in the number of NOR-bearing chromosomes was found between the sampled populations of $P$. nordestina, ranging from 3 to 4 . This study also clarified previous conflicting results concerning the occurrence of inter- and intrapopulation NOR variation in $P$. rohdei. The variation, confirmed by $45 \mathrm{~S}$
\end{abstract}


rDNA fluorescence in situ hybridization analysis, was congruent with results obtained from AgNOR-banding in all species.

Key words: Chromosome; Evolution; 45S rDNA; AgNOR-banding; Anura

\section{INTRODUCTION}

The genus Phyllomedusa comprises 30 recognized species, 22 of which are found in Brazil (Frost, 2011). Based on morphological, molecular, and acoustic characters, 26 species have been arranged into 4 species-groups, i.e., the P. burmeisteri group (Pombal Jr. and Haddad, 1992), the $P$. hypochondrialis group (Caramaschi, 2006), the $P$. perinesos group (Cannatella, 1982), and the $P$. tarsius group (Barrio-Amorós, 2006). The remaining species are still in need of placement (Faivovich et al., 2009).

Faivovich et al. (2009) pointed out the need for more detailed investigations of some Phyllomedusa groups. P. nordestina shows a high level of intraspecific sequence divergence (up to $10.4 \%$ ) in the mitochondrial cytochrome b gene, and $P$. rohdei appears to be paraphyletic by forming a clade with $P$. megacephala. Additionally, P. rohdei from different locations showed high p-distance values, suggesting the presence of additional taxa within this group. P. bahiana was originally described as a P. burmeisteri subspecies by Lutz (1950), and was later elevated to species status by Silva-Filho and Juncá (2006). Faivovich et al. (2009) provided additional support for this placement based on molecular data. However, Pombal Jr. and Haddad (1992) observed specimens with intermediate thigh color patterns across the species range, suggesting the presence of putative fertile hybrids between P. bahiana and P. burmeisteri.

The genus Phasmahyla (Cruz, 1990) contains species that were formerly included in the Phyllomedusa gutata group. Morphological and molecular characters have since revealed this genus to be a sister group of Phyllomedusa (Faivovich et al., 2009), which makes Phasmahyla an important group for understanding the evolution of karyotypes in Phyllomedusa.

Cytogenetic analysis is an important complementary approach to assist studies of evolutionary relationships at the species and higher taxonomic levels. However, chromosomal data on Phyllomedusa and related genera remain scarce, particularly with respect to the use of molecular cytogenetic techniques. Barth et al. (2009) identified high variation in the number of nucleolus organizer regions (NOR) in populations of $P$. rohdei from Bahia State. Paiva et al. (2010) observed a similar pattern in one population from São Paulo State. Morando and Hernando (1997) also observed this pattern of variation in P. hypochondrialis.

The NOR is a chromosomal site containing ribosomal genes, which can be located either directly by fluorescent in situ hybridization (FISH) of ribosomal DNA probes or indirectly, by silver nitrate staining (AgNOR-banding). The combined use of these 2 techniques is useful since AgNOR-banding enables detection of only active NORs (Sumner, 1990), while the FISH technique can locate every ribosomal DNA cluster in the genome. Moreover, several studies demonstrated that in some organisms, silver nitrate can bind to some chromosomal regions even in the absence of an NOR (e.g., Utsumi and Takehisa, 1974; Dobigny et al., 2002). Frequently, these rDNA-free silver nitrate-positive regions correspond to heterochromatins (e.g., Fujiwara et al., 1998).

In this study, we analyzed the chromosomal profiles of P. nordestina and P. rohdei, 
which are included in the P. hypochondrialis group, P. bahiana from the P. burmeisteri group, and Phasmahyla spectabilis, using conventional and molecular cytogenetic techniques.

\section{MATERIAL AND METHODS}

Specimens of P. bahiana, P. rohdei, P. nordestina, and P. spectabilis were collected from different localities in the State of Bahia, Brazil. Vouchers were deposited in the Herpetological Collection at Universidade Estadual de Santa Cruz (MZUESC), BA, Brazil (Figure 1 and Table 1).

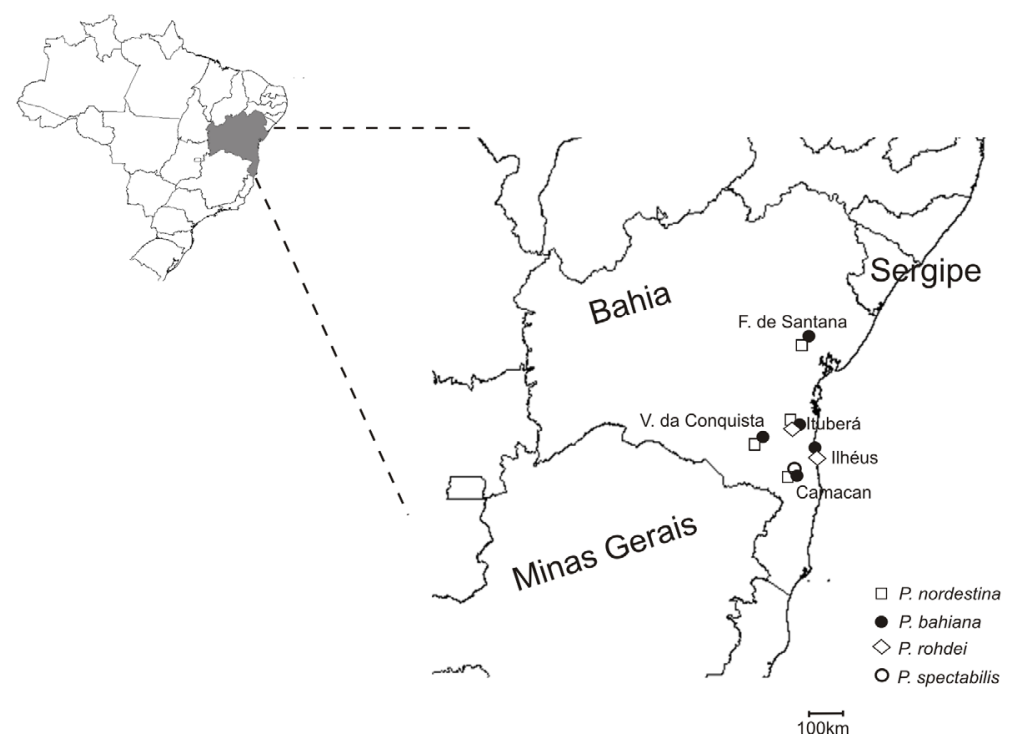

Figure 1. Map of the sampling localities. Feira de Santana $\left(12^{\circ} 06^{\prime} \mathrm{S} 39^{\circ} 02^{\prime} \mathrm{W}\right)$, Ilhéus $\left(14^{\circ} 47^{\prime} \mathrm{S} 39^{\circ} 10^{\prime} \mathrm{W}\right)$, Camacan

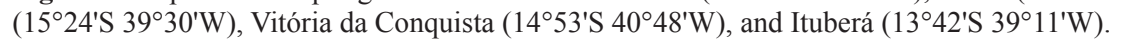

\begin{tabular}{|c|c|c|c|}
\hline Genus & No. of specimens & Locality & Voucher number \\
\hline \multirow[t]{5}{*}{ Phyllomedusa bahiana } & 12 & Feira de Santana & MZUESC7041-MZUESC7052 \\
\hline & 1 & Vitória da Conquista & MZUESC10862 \\
\hline & 2 & Ituberá & MZUESC6978; MZUESC6979 \\
\hline & 7 & Camacan & $\begin{array}{l}\text { MZUESC6989; MZUESC6996; MZUESC6998; MZUESC7000; } \\
\text { MZUESC7002; MZUESC7014; MZUESC7017 }\end{array}$ \\
\hline & 10 & Ilhéus & $\begin{array}{l}\text { MZUESC5615; MZUESC6961-MZUESC6965; MZUESC6973; } \\
\text { MZUESC6975; MZUESC6993; MZUESC6994 }\end{array}$ \\
\hline \multirow[t]{2}{*}{ Phyllomedusa rohdei } & 6 & Ituberá & $\begin{array}{l}\text { MZUESC7030; MZUESC7032; MZUESC7034; MZUESC7036; } \\
\text { MZUESC7056; MZUESC } 6986\end{array}$ \\
\hline & 8 & Ilhéus & $\begin{array}{l}\text { MZUESC5608-MZUESC5610; MZUESC5612-MZUESC5614; } \\
\text { MZUESC6982; MZUESC6985 }\end{array}$ \\
\hline \multirow[t]{4}{*}{ Phyllomedusa nordestina } & 5 & Vitória da Conquista & MZUESC7003-MZUESC7005; MZUESC7010; MZUESC7013 \\
\hline & 1 & Camacan & MZUESC6995 \\
\hline & 5 & Ituberá & $\begin{array}{l}\text { MZUESC7027; MZUESC7029; MZUESC7057; MZUESC7059; } \\
\text { MZUESC10857 }\end{array}$ \\
\hline & 1 & Feira de Santana & MZUESC7040 \\
\hline Phasmahyla spectabilis & 3 & Camacan & MZUESC10373-MZUESC10375 \\
\hline
\end{tabular}


For cytological preparations, samples were pretreated with $1 \%$ colchicine, 10 $\mathrm{h}$ prior to dissection. Gut cells were then extracted and prepared following methods described in Schmid (1978). Chromosomes were stained using 5\% Giemsa solution. A minimum of 5 slides per specimen and 5 metaphases per slide were analyzed. AgNORbanding followed methods described in Howell and Black (1980), with a few modifications: we used $25 \%$ silver nitrate solution and incubated the slides at $50^{\circ} \mathrm{C}$ for approximately $30 \mathrm{~min}$. The slides were analyzed and the best quality metaphases were photographed using an Olympus CX-41 microscope equipped with a digital camera. Chromosomes were classified according to Green and Sessions (1991) nomenclature as metacentric, submetacentric, and subtelocentric, and were organized in decreasing order of length.

FISH was performed using the HM123 plasmid probe, containing part of the $45 \mathrm{~S}$ rDNA sequence from Xenopus laevis (Meunier-Rotival et al., 1979), labeled with cyanine 3-dUTP (dUTP-Cy3) by nick translation. FISH procedures followed methods of Moscone et al. (1996), with a few modifications, at $72 \%$ stringency. Slides were analyzed in an Olympus BX-51 epifluorescence microscope and the images were captured using the ImageProPlus software.

\section{RESULTS}

All Phyllomedusa and P. spectabilis specimens showed $2 \mathrm{n}=26$ chromosomes. $P$. spectabilis showed submetacentric chromosomes in pairs 1 to $6,9,10$, and 12 , metacentric chromosomes in pairs 8,11 , and 13 , while pair 7 was subtelocentric. P. bahiana showed a karyotype with submetacentric chromosomes in pairs 1 to $6,9,10$, and 12 , metacentric chromosomes in pairs 7, 11, and 13, and pair 8 was subtelocentric. P. nordestina showed metacentric chromosomes in pairs $1,4,6$, and 8 to 13 , submetacentric chromosomes in pairs 2, 3, and 5, and pair 7 was subtelocentric (Figure 2A-C).

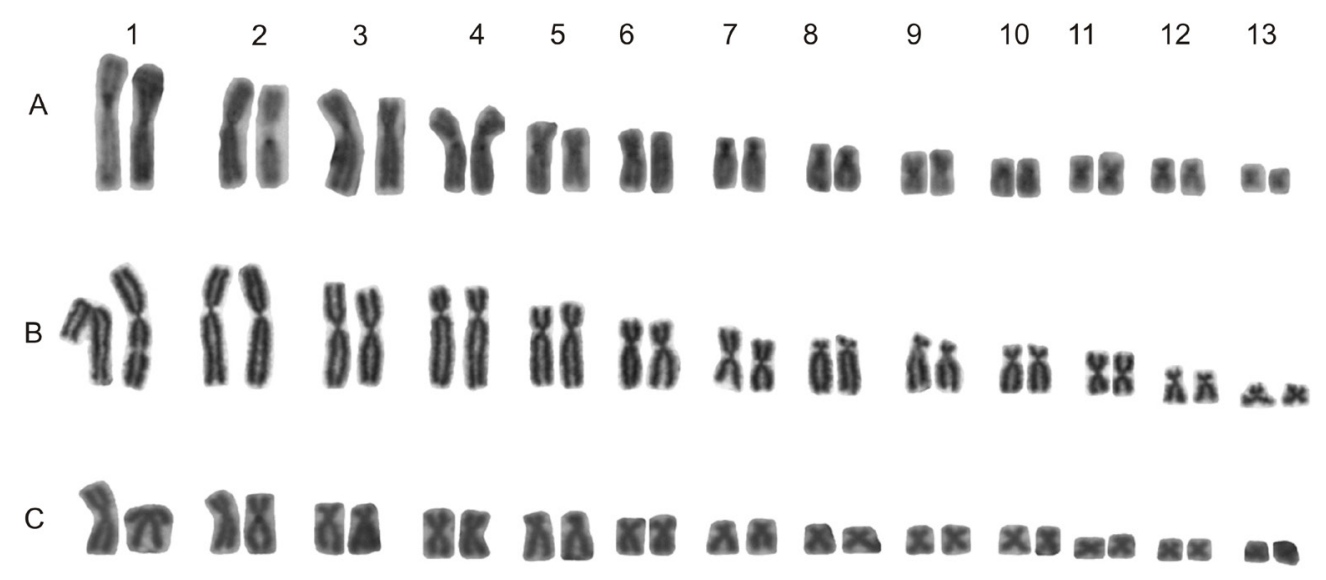

Figure 2. Karyograms of A. Phasmahyla spectabilis B. Phyllomedusa bahiana and C. Phyllomedusa nordestina. 
P. spectabilis had the NOR located near the centromere of the 2 nd chromosome pair (Figure 3A). P. bahiana also showed centromere proximal NORs, which were located in the long arm of the 9th chromosome pair. Most P. bahiana individuals showed a heteromorphism in NOR length. Samples with 2 alternative homomorphic states were also observed (Figure 3B and C). P. nordestina showed variation in the number of interstitial AgNOR bands across different sampling locations, ranging from 2 to 3 NOR-carrying chromosomes (Figure 3D and E). In specimens of the Ituberá population, 3 AgNOR bands were located in one of the chromosomes of the 9th pair and in both homologues of the 11th pair. However, in Vitória da Conquista and Camacan samples, NORs were only observed in the 11th chromosome pair.

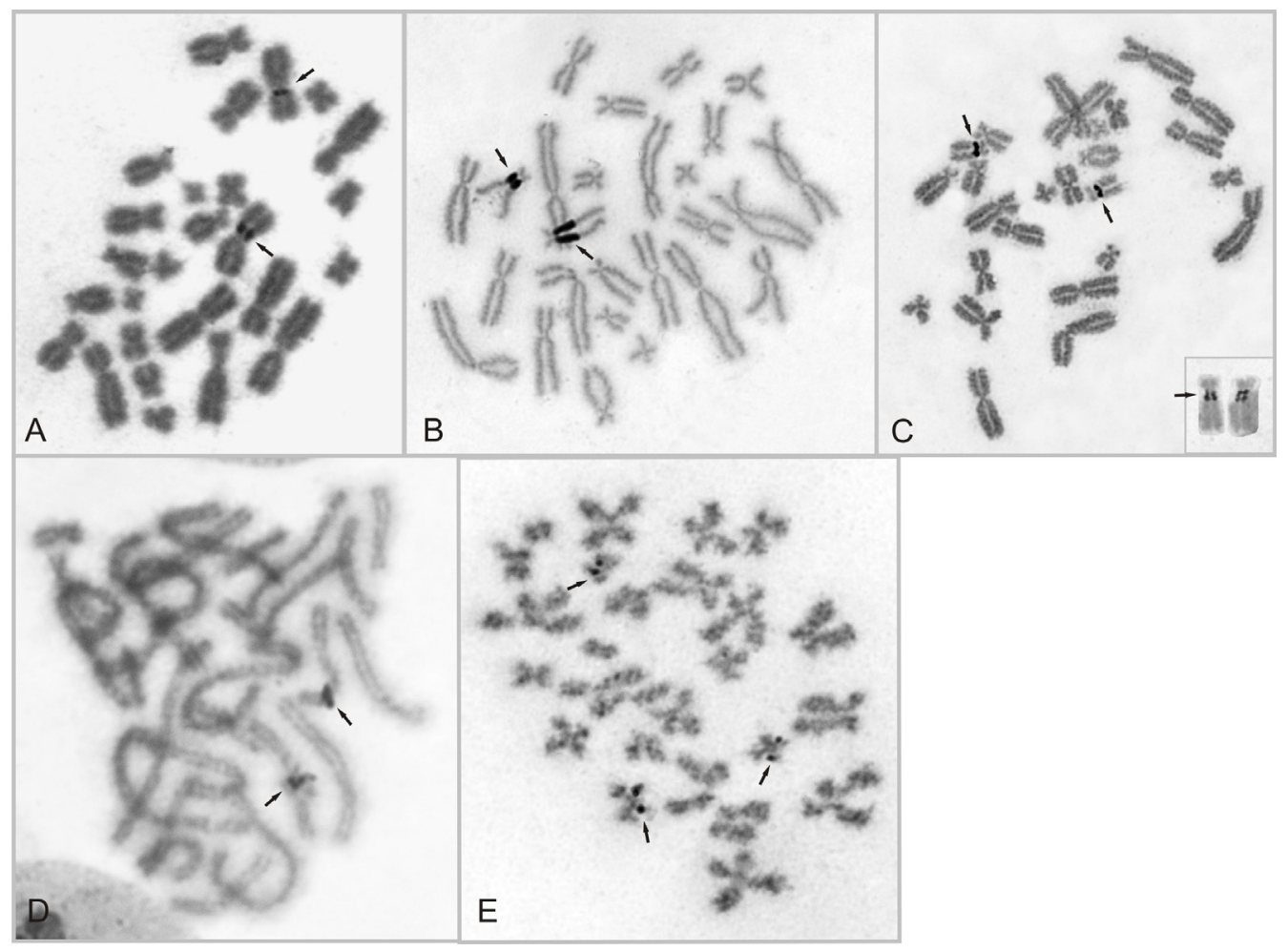

Figure 3. Metaphases labeled by AgNOR-banding. A. Phasmahyla spectabilis showing 2 chromosomes carrying the NOR; B. C. Phyllomedusa bahiana showing the heteromorphic NOR and homomorphic short NOR and the duplicated NOR pattern (in the box), respectively; D. E. Phyllomedusa nordestina showing 2 and 3 chromosomes with NOR, respectively.

Results of 45S rDNA in situ hybridization were congruent with the AgNOR-banding pattern in all species analyzed (Figure 4). These results also showed variation in the number of $45 \mathrm{~S}$ rDNA clusters in $P$. rohdei, which ranged from 1 to 4 chromosomes containing rDNA gene clusters (Figure 4E-G). Their locations were near the telomeric region in the 9th and 10th chromosome pairs. 

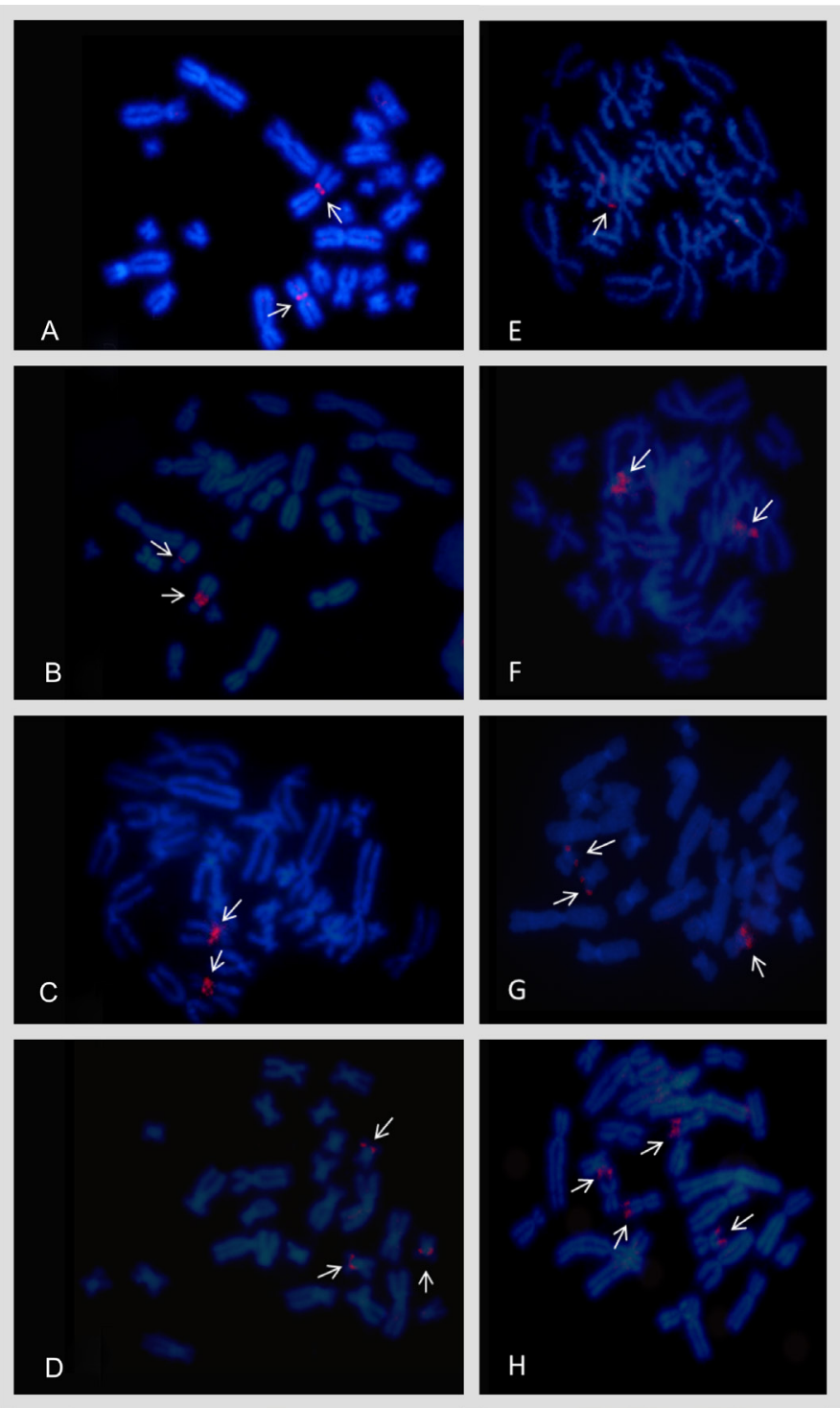

Figure 4. Metaphases labeled by 45S rDNA fluorescence in situ hybridization. A. Phasmahyla spectabilis; B. C. Phyllomedusa bahiana showing the heteromorphic and homomorphic NOR, respectively; D. Phyllomedusa nordestina; E.-H. Phyllomedusa rohdei showing 1 to 4 chromosomes with NORs in different individuals.

\section{DISCUSSION}

Previously studied Phyllomedusa species exhibited a conservative chromosome number of $2 \mathrm{n}=26$ (Haddad et al., 1994; Morando and Hernando, 1997; Kasahara et al., 2007; Bruschi et al., 2012), with the exception of P. tetraploidea, which had $2 \mathrm{n}=52$ chromosomes. The increase in chromosome number was most likely due to a polyploidy event in a lineage 
with the $2 \mathrm{n}=26$ karyotype (Kasahara et al., 2007; Brunes et al., 2010). This chromosome number stability among Phyllomedusa species was confirmed in the present study and, for the first time, also reported for $P$. spectabilis.

$P$. spectabilis showed other karyotype similarities with $P$. bahiana. For example, the 7th chromosome pair in P. spectabilis showed a very similar morphology to the 8th chromosome pair of $P$. bahiana. One major differentiation was found with respect to the NOR position, which was located in the 2nd chromosome pair in P. spectabilis but in the 9th chromosome pair in P. bahiana. The karyotype similarities observed between these Phyllomedusa and Phasmahyla species agree with recent molecular phylogenetic analyses (Faivovich et al., $2005,2009)$ that place them as sister groups.

Since most species showed exclusively short NOR bands, the peculiar NOR length heteromorphism exhibited by P. bahiana seems to have been more recently derived as a result of a tandem amplification of rDNA clusters in this species. Similar NOR-length heteromorphisms were found in other anurans (Schmid, 1982; Lourenço et al., 2000; Busin et al., 2000; Bruschi et al., 2012), and this variation has been formerly attributed to tandem amplification of rRNA genes or of a whole NOR segment (Schmid, 1982; King et al., 1990).

Schmid (1982) suggested that amplified NORs would be lethal in their homomorphic state, since the chromosome rearrangement could cause additional structural alterations in the NOR-adjacent segments that contain some functionally important genes. This assumption follows from an analysis of 260 individuals from 23 genera that lack the homomorphic amplified state. However, in P. bahiana, the amplification seems to be well tolerated, since it showed a feasible rearrangement in homozygosis.

The occurrence of multiple and variable rDNA clusters observed in $P$. rohdei using FISH analysis confirmed the variation previously reported by Barth et al. (2009) and Paiva et al. (2009) based on AgNOR-banding. Morando and Hernando (1997) found similar results in $P$. hypochondrialis using AgNOR-banding. P. nordestina is now included in this list as revealed by the present FISH and AgNOR-banding analyses.

Bruschi et al. (2012) found only one pair of chromosomes containing rDNA clusters in populations of $P$. rohdei and $P$. nordestina from Bahia State. The failure to detect variation in this case may have been related to their adoption of a more limited sampling strategy. Moreover, the morphology of the 9th chromosome pair, which was found to contain the NOR in the present analysis, also differs from that observed in Bruschi et al. (2012), who described it as a submetacentric chromosome pair. These differences most likely reflect small morphological variations in the same chromosomes, which can occur because of different chromosomal preparations.

Multiple NOR sites in karyotypes are usually due to chromosomal rearrangements such as inversions and translocations (King et al., 1990), rDNA cistron amplifications (Macgregor and Kezer, 1973), and the presence of genetic transposable elements (Schubert and Wobus, 1985). However, an explanation for differences among species in their susceptibility to molecular reorganization of rDNA clusters is still lacking. Results of the present study contrast with the major pattern of only one chromosome pair with NOR that is found in the other Phyllomedusa and related species studied so far; however, multiple NORs have been described in several other anuran species (e.g., Wiley et al., 1989; Lourenço et al., 1998, 2000; Veiga-Menoncello et al., 2003; Amaro-Ghilardi et al., 2006; Silva et al., 1999, 2006), indicating that this variation is common in this group. 
This study provides the first cytogenetic data for P. bahiana and P. spectabilis, and clarified previous conflicting results concerning inter- and intra-population NOR variation in $P$. rohdei and $P$. nordestina. The data shown here improve upon current knowledge about $P$ hyllomedusa/Phasmahyla karyotype evolution and raise new questions regarding their chromosomal organizations and variation. The new cytogenetic results confirmed higher chromosome variability in the Phyllomedusa species, and reiterated the need for taxonomic review of this group combining morphology, bioacoustics, molecular and cytogenetic data.

\section{ACKNOWLEDGMENTS}

We thank F.A. Gaiotto and C. Mariano for comments on the manuscript. Coordenação de Aperfeiçoamento de Pessoal de Nível Superior (CAPES) and Fundação de Amparo à Pesquisa do Estado da Bahia (FAPESB) provided scholarships to A. Barth, and Conselho Nacional de Desenvolvimento Científico e Tecnológico (CNPq) provided research grants to M. Solé and M.A. Costa. Center for Biodiversity Studies of the Michelin Ecological Reserve provided support during fieldwork, and RAN/IBAMA provided the collection permit (\#10830-1).

\section{REFERENCES}

Amaro-Ghilardi RC, Skuk G, de Sá RO, Rodrigues MT, et al. (2006). Karyotypes of eight species of Leptodactylus (Anura, Leptodactylidae) with a description of a new karyotype for the genus. Phyllomedusa 5: 119-133.

Barrio-Amorós CL (2006). A new species of Phyllomedusa (Anura: Hylidae: Phyllomedusinae) from northwestern Venezuela. Zootaxa 1309: 55-68.

Barth A, Solé M and Costa MA (2009). Chromosome polymorphism in Phyllomedusa rohdei populations (Anura: Hylidae). J. Herpetol. 43: 676-679.

Brunes TO, Sequeira F, Haddad CF and Alexandrino J (2010). Gene and species trees of a Neotropical group of treefrogs: genetic diversification in the Brazilian Atlantic Forest and the origin of a polyploid species. Mol. Phylogenet. Evol. 57: 1120-1133.

Bruschi DP, Busin CS, Siqueira S and Recco-Pimentel SM (2012). Cytogenetic analysis of two species in the Phyllomedusa hypochondrialis group (Anura, Hylidae). Hereditas 149: 34-40.

Busin CS, Vinciprova G and Recco-Pimentel SM (2000). Chromosomal rearrangements as the source of variation in the number of chromosomes in Pseudis (Amphibia, Anura). Genetica 110: 131-141.

Cannatella DC (1982). Leaf-frogs of the Phyllomedusa perinesos group (Anura: Hylidae). Copeia 501-513.

Caramaschi U (2006). Redefinição do grupo Phyllomedusa hypochondrialis, com redescriçãoo de $P$. megacephala (Miranda-Ribeiro, 1926), revalidação de P. azurea (COPE, 1862) e descrição de uma nova espécie (Amphibia, Anura, Hylidae). Arq. Mus. Nac. 64: 159-179.

Cruz CAG (1990). Sobre as relações intergenéricas de Phyllomedusinae da Floresta Atlântica (Amphibia, Anura, Hylidae). Rev. Bras. Biol. 50: 709-726.

Dobigny G, Ozouf-Costaz C, Bonillo C and Volobouev V (2002). "Ag-NORs" are not always true NORs: new evidence in mammals. Cytogenet. Genome Res. 98: 75-77.

Faivovich J, Haddad CFB, Garcia PCA, Frost DR, et al. (2005). Systematic review of the frog family Hylidae, with special reference to Hylinae: Phylogenetic analysis and taxonomic revision. Bull. Am. Mus. Nat. Hist. 294: 1-240.

Faivovich J, Haddad CFB, Baêta D, Jungfer KH, et al. (2009). The phylogenetic relationships of the charismatic poster frogs, Phyllomedusinae (Anura, Hylidae). Cladistics 26: 227-261.

Frost DR (2011). Amphibian Species of the World. Internet Reference. Available at [http://research.amnh.org/vz/ herpetology/amphibia/]. Accessed November 15, 2012.

Fujiwara A, Abe S, Yamaha E, Yamazaki F, et al. (1998). Chromosomal localization and heterochromatin association of ribosomal RNA gene loci and silver-stained nucleolar organizer regions in salmonid fishes. Chromosome Res. 6: 463-471.

Green DM and Sessions SK (1991). Nomenclature for Chromosomes. In: Amphibian Cytogenetics and Evolution (Green DM and Sessions SK, eds.). Academic Press, San Diego, 431-432. 
Haddad CFB, Pombal Jr JP and Batistic RF (1994). Natural hybridization between diploid and tetraploid species of leaffrogs genus Phyllomedusa (Amphibia). J. Herpetol. 28: 425-430.

Howell WM and Black DA (1980). Controlled silver-staining of nucleolus organizer regions with a protective colloidal developer: a 1-step method. Experientia 36: 1014-1015.

Kasahara S, Campos JRC, Catroli GF and Haddad CFB (2007). Cytogenetics of Phyllomedusa distincta $(2 \mathrm{n}=2 \mathrm{x}=26)$, Phyllomedusa tetraploidea $(2 \mathrm{n}=4 \mathrm{x}=52)$ and their triploid hybrids $(2 \mathrm{n}=3 \mathrm{x}=39) .16$ th Int. Chromosome Conf. Chromosome Res. 5: 10.

King M, Contreras N and Honeycutt RL (1990). Variation within and between nucleolar organizer regions in Australian hylid frogs (Anura) shown by $18 \mathrm{~S}+28 \mathrm{~S}$ in-situ hybridization. Genetica $80:$ 17-29.

Lourenço LB, Recco-Pimentel SM and Cardoso AJ (1998). Polymorphism of the nucleolus organizer regions (NORs) in Physalaemus petersi (Amphibia, Anura, Leptodactylidae) detected by silver staining and fluorescence in situ hybridization. Chromosome Res. 6: 621-628.

Lourenço LB, Garcia PC and Recco-Pimentel SM (2000). Cytogenetics of two species of Paratelmatobius (Anura: Leptodactylidae), with phylogenetic comments. Hereditas 133: 201-209.

Lutz B (1950). Anfíbios anuros da coleção Adolpho Lutz: V. locomoção e estrutura das extremidades, Va. Phyllomedusa (P.) burmeisteri distincta A. lutz: Vb. Aplastodicus perviridis A. Lutz. Mem. Inst. Oswaldo Cruz 48: 599-637.

Macgregor HC and Kezer J (1973). The nucleolar organizer of Plethodon cinereus cinereus (Green). I. Location of the nucleolar organizer by in situ nucleic acid hybridization. Chromosoma 42: 415-426.

Meunier-Rotival M, Cortadas J, Macaya G and Bernardi G (1979). Isolation and organization of calf ribosomal DNA. Nucleic Acids Res. 6: 2109-2123.

Morando M and Hernando A (1997). Localización cromosómica de genes ribosomales activos en Phyllomedusa hypochondrialis y $P$. sauvagii (Anura: Hylidae). Cuad. Herpetol. 11: 31-36.

Moscone EA, Matzke MA and Matzke AJ (1996). The use of combined FISH/GISH in conjunction with DAPI counterstaining to identify chromosomes containing transgene inserts in amphidiploid tobacco. Chromosoma 105: 231-236.

Paiva CR, Nascimento J, Silva APZ, Bernarde S, et al. (2010). Karyotypes and Ag-NORs in Phyllomedusa camba De La Riva, 1999 and P. rohdei Mertens, 1926 (Anura, Hylidae, Phyllomedusinae): Cytotaxonomic considerations. Ital. J. Zool. 77: 116-121.

Pombal Jr JP and Haddad CFB (1992). Espécies de Phyllomedusa do grupo burmeisteri do Brasil oriental, com descrição de uma espécie nova (Amphibia, Hylidae). Rev. Bras. Biol. 52: 217-229.

Schmid M (1978). Chromosome banding in Amphibia. I. Constitutive heterochromatin and nucleolus organizer regions in Bufo and Hyla. Chromosoma 66: 361-388.

Schmid M (1982). Chromosome banding in Amphibia. VII. Analysis of the structure and variability of NORs in Anura. Chromosoma 87: 327-344.

Schubert I and Wobus U (1985). In situ hybridization confirms jumping nucleolus organizing regions in Allium. Chromosoma 92: 143-148.

Silva-Filho ISN and Juncá FA (2006). Evidence of full species status of the neotropical leaf-frog Phyllomedusa burmeisteri bahiana (A. Lutz, 1925) (Amphibia, Anura, Hylidae). Zootaxa 1113: 51-64.

Silva AP, Haddad CF, Galassi GG and Kasahara S (2006). Multiple nucleolus organizer regions in Leptodactylus mystacinus (Amphibia, Anura) and comments on its systematic position in the L. fuscus group based on cytogenetic and molecular analyses. Genetica 127: 35-44.

Silva AP, Haddad CF and Kasahara S (1999). Nucleolus organizer regions in Physalaemus cuvievi (Anura, Leptodactylidae), with evidence of a unique case of Ag-NOR variability. Hereditas 131: 135-141.

Sumner AT (1990). Chromosome Banding. Unwin Hyman, London.

Utsumi S and Takehisa S (1974). Heterochromatin differentiation in Trillium kamtschaticum by ammoniacal silver reaction. Exp. Cell Res. 86: 398-401.

Veiga-Menoncello AC, Lima AP and Recco-Pimentel SM (2003). Cytogenetic analysis of four central Amazonian species of Colostethus (Anura - Dendrobatidae) with a diploid complement of 22 chromosomes. Hereditas 139: 189-198.

Wiley JE, Little ML, Romano MA, Blount DA, et al. (1989). Polymorphism in the location of the 18S and 28S rRNA genes on the chromosomes of the diploid-tetraploid treefrogs Hyla chrysoscelis and H. versicolor. Chromosoma 97 : 481-487. 